\title{
Miranda
}

Revue pluridisciplinaire du monde anglophone /

Multidisciplinary peer-reviewed journal on the English-

speaking world

$12 \mid 2016$

Mapping gender. Old images ; new figures

\section{"Women, Ladies, Girls, Gals...": Ronald Reagan and the Evolution of Gender Roles in the United States}

\section{Françoise Coste}

\section{OpenEdition}

Journals

\section{Electronic version}

URL: https://journals.openedition.org/miranda/8602

DOI: 10.4000/miranda.8602

ISSN: 2108-6559

Publisher

Université Toulouse - Jean Jaurès

\section{Electronic reference}

Françoise Coste, "'Women, Ladies, Girls, Gals...": Ronald Reagan and the Evolution of Gender Roles in the United States", Miranda [Online], 12 | 2016, Online since 02 March 2016, connection on 21

September 2021. URL: http://journals.openedition.org/miranda/8602 ; DOI: https://doi.org/10.4000/ miranda.8602

This text was automatically generated on 21 September 2021.

\section{(c) $(1)$}

Miranda is licensed under a Creative Commons Attribution-NonCommercial-NoDerivatives 4.0 International License. 


\title{
"Women, Ladies, Girls, Gals...": Ronald Reagan and the Evolution of Gender Roles in the United States
}

\author{
Françoise Coste
}

1 Today, Ronald Reagan's presidency is often remembered as a difficult period for American women, an era of 'backlash' against women's rights, to use Susan Faludi's famous term. ${ }^{1}$ In many respects, this negative assessment makes sense. Both his personal life (he was born in 1911 in rural Illinois, in a deeply Evangelical family) and his Hollywood years (where his success was largely based on his appeal to female audiences, as Warner Brothers' publicists marketed him as the all-American heterosexual hero, "tall and handsome," with "nothing of the pretty boy about him" since "virility [was] his outstanding characteristic") explain that Ronald Reagan considered his popularity and his success with women as the most normal thing in the world (Vaughn 70). This tended to give him a very traditional vision of gender roles, rather typical of the white, middle and upper-class post-war United States. Both men and women had clearly-defined specific functions, which were mutually exclusive: men belonged to the professional world and had to succeed since they were solely responsible for supporting their family, while their wives belonged to the private and domestic sphere where they should nurture the children (Dicker 12-13, 64-65). The influence of this ideological framework was obvious when Ronald Reagan married his second wife, Nancy Davis, in 1952 (he had divorced his first wife, actress Jane Wyman, in 1948). Nancy was an actress herself. When they got married, Reagan secretly hoped that she would stop working and accept a more subordinate role in their family-particularly from an economic point of view-as he admitted in his first autobiography, published in 1965:

Her career and what would happen to it had entered my mind once or twice, and while I knew I'd be happier if the career ran second-way behind-I knew also I could never say 'give it up.'

But he "should not have worried" because he had found in her his perfect woman. Indeed 
it was ingrained in her to simply say, "If you try to make two careers work, one of them has to suffer." She was fair. She said, "Maybe some women can do it, but not me." (Reagan 1965, 273-274)

3 And thus did Nancy Reagan become a supportive housewife for the rest of her life. Given this very particular background, Ronald Reagan was no friend of the feminist movement which had emerged in the Sixties. Its demands regarding work, reproductive health, or political participation, threatened to weaken the foundations of his idealized interpretation of gender roles. Women's groups were consequently worried when Ronald Reagan ran for the presidency on an anti-feminist agenda in 1980 and won. But his anti-feminist initiatives ran into many obstacles and his presidency paradoxically marked a period of progress for many American women.

\section{An anti-feminist agenda}

Ronald Reagan's 1980 presidential campaign had a strong moral component. This was in great measure the result of the political mobilisation of conservative Evangelical Protestants in the 1970s and the emergence of the Christian Right-by 1980 the Moral Majority, the main Evangelical lobby, had almost half a million members (Diamond 174). ${ }^{2}$ These new activists had three priorities, and they were directly related to the sexual revolution of the 1960s and the issue of women's rights: the denunciation of homosexuality, the fight against abortion (which was famously declared constitutional by the Supreme Court with its Roe v. Wade decision in 1973), and the rejection of the ERA (the Equal Rights Amendment) (Martin 162-166, 193-194). In the late 1970s, Ronald Reagan quickly understood the incredible electoral potential of the Christian Right. More than any political leader before him, he explicitly wooed Evangelicals in the runup to his presidential campaign and showed them he shared their culture and their vision of the world by resorting to the Evangelical message he had learned as a child. Thus, when he met Jerry Falwell, the head of the Moral Majority, for the first time in 1980, he made a strong impression when he confided to him that he shared his eschatological interpretation of the Book of Revelation (Strober and Strober 31). He also became a vocal presence in the Christian press of that period, assuring its readers that the cultural excesses of the Sixties had been an aberration and that it was time to go back to a more traditional way of life:

the time ha[d] come to turn to God and reassert our trust in Him for our great nation's healing. We need to join forces to reclaim the great principles embodied in the Judeo-Christian traditions and in Holy Scriptures. ${ }^{3}$

Concretely, for candidate Reagan in 1980, this vision meant two things above anything else. The first one was abortion, and he promised to support, if he were elected, a constitutional amendment banning abortion everywhere in the country. The question had become central for the Christian Right and, as it happened, Reagan had a lot to expiate in this regard. Despite his moral conservatism, as Governor of California, he had signed a law in 1967 which had legalized abortion in the state (interestingly, it seems that Nancy Reagan played a relative role in convincing her husband to sign this law) (Colacello 361). During his presidential campaign, Reagan found an interesting way to explain this decision. Deep down, he had always condemned abortion since "interrupting a pregnancy means the taking of a human life." If he had signed a "permissive bill," it was only because of his "inexperience." He had been in office for less than a year when the state legislators had voted for this bill. Before signing it, he 
had done a lot of thinking and had concluded that "it could only be justified to save a human life." But then this definition was broadened to include the "health of the mother" ("meaning the permanent damage to the health of a mother if she went through her pregnancy."). This made sense to him as well, so he signed the law without realizing that this health exception was a "loophole that I had not seen" which led to the "violation of the spirit of the legislation by the very groups who were supposed to police it," in particular "psychiatrists" who, according to him, abusively justified too many abortions. But he had learned his lesson, he was sorry, and he was now staunchly opposed to abortion (Reagan 2004, 197-198).

6 The second moral priority for candidate Reagan was the ERA. The Equal Rights Amendment, which aimed at inscribing gender equality in the Constitution ("Equality of rights under the law shall not be denied or abridged by the United States or by any state on account of sex.") had been voted by Congress in 1972. The following step was its ratification by three-quarters of the states, which many conservative groups were trying to prevent-an effort enthusiastically supported by Reagan in 1980. Even more than the question of abortion, his arguments regarding the ERA may be the best way to understand his conception of women's rights. The first thing to stress is that Reagan was a smart politician and that when he criticized the ERA, he took pains to say that this did not mean he did not believe in gender equality. Rather, he believed the ERA was the wrong way to guarantee gender equality and that it would actually hurt women. In his convention speech, he explained that despite his opposition to the ERA, he would "establish a liaison with the 50 governors to encourage them to eliminate, where it exists, discrimination against women." (Reagan, Convention Speech).

7 However, this apparent concern for women betrayed a traditional conception of gender roles in modern American society and a stark refusal to consider any evolution in the typical post-war myth of the suburban nuclear family where the father was the breadwinner and the mother the homemaker. For example, like many anti-ERA activists, Reagan was convinced that the ERA would force women to be drafted into the military. This was a bad thing according to him, not because women did not necessarily want to become soldiers, but because the "high physical or skill standards" of the military "would have to be equal for men and women, so many standards might have to be lowered, and the quality of the military would deteriorate." Similarly, he was worried about the economic impact of the ERA on divorced women, not because it may be hard to force deadbeat fathers to pay their alimony, but because women would have to leave the domestic sphere-as if the presence of women, even mothers, in the workplace had not already become a reality by 1980 , a reality of which Ronald Reagan was seemingly unaware:

Traditionally, a divorced woman with small children has been entitled to support payments from the father, since caring for her children prevented her from holding a job. ... The availability of day care centers would permit a woman to 'support herself through employment'. Thus... she might be forced to place her children in day care centers eight hours a day so that she could work to support them. ${ }^{4}$

Interestingly, some campaign advisors started to worry that this type of rhetoric could have what they described as a "negative effect" on Reagan's candidacy. After all, most polls indicated a majority of Americans did support the ratification of the ERA and research showed that a majority of women found candidate Reagan "cool" and "aloof." The most concerned staffers were women. The first one to sound the alarm, in the spring of 1980, was Dodie Truman Livingston. She was bothered by the fact that there 
was not a single woman in the campaign's high command. She thought this was "a mistake," as, in the eyes of the media, the campaign consequently looked like "a good old boys' club." What's more, because of this all-male atmosphere, Reagan and his advisors were unable to connect with the experience of "a lot of women" who were "trying to put together a lifestyle that enables them to have a career... but also a strong family life." This too was a political handicap as "this struggle is not well understood by men... and yet, it deserves a great deal of attention." Ignoring half the electorate was not a smart strategy and she advised the campaign to "open more doors to women," which was bound, according to her, to "pay big dividends."

Such warnings were heeded to a certain extent, although the campaign's answers proved utterly inadequate. It was decided for example that, "wherever possible and appropriate," on TV and in the press, the campaign would use pictures showing Reagan "with women." The all-male senior staff was also coached on what campaign strategists called the "terminology preferable to modern women" to avoid gaffes in their media appearances. The idea was to "help sensitize the campaign" about "words and phrases in common usage among today's women"-which amounted to admitting that Reagan and his team had disregarded the demands of the women's movement until then. Thus Ronald Reagan and his top advisors learned that the correct term to describe "a female adult" was "woman," "not girl or gal (emphasis in the original)," that "Ladies" was only a "a polite form of address for women-to be used only when 'gentlemen' would be used for men," that "women's libber" was "a derogatory slang term for Feminist" and that, precisely, "a feminist" was "a person, man or woman, who believes in equality of opportunity regardless of gender." They should also be careful when talking in public and not confuse a "housewife" ("a woman married to a house") with a "homemaker" ("a person, man or woman, who is responsible for maintaining a home"). ${ }^{8}$ Potentially less superficial was the nomination of a woman, Marilyn Thayer, to join the senior staff as a "special advisor," and the formation within the campaign of a Women's Policy Board.

10 But these gestures were insufficient to hide the profound disconnection between candidate Reagan and women's issues. Thayer's nomination only took place in September 1980, six weeks before the election. Adding insult to injury, she was not treated by the rest of the staff as a policy expert able to help the campaign on all issues, but rather as a "consultant" who would "review ... policy statements and other publications of the campaign which include womens [sic] and family issues." As for the Women's Policy Board, it quickly proved an embarrassment for the campaign. Most of the women Reagan had appointed to the Board were moderate Republicans who supported abortion rights and the ERA. When they realized this, Christian conservative groups loudly complained, which pushed the campaign into panic mode. After a few days, Bill Casey, Reagan's campaign manager, decided to form a second commission, the Women's Policy Committee, whose members would be picked among anti-abortion and anti-ERA activists (Martin 214). ${ }^{10}$

11 In this context, women's groups were unsurprisingly harsh in their criticism of the Reagan campaign. For Reagan himself, this made no sense and, rather condescendingly, he blamed them for this situation. He saw himself as a great champion of women's rights. As he explained to NOW (the National Organization for Women):

As governor [of California], I signed legislation to prohibit sexual discrimination in employment and business matters, [and] bills to establish the right of married women to obtain credit in their own name and [...] to allow married women to buy 
and sell securities in their own name, [to] equalize a woman's right to change her name, [...] to extend state unemployment disability insurance benefits to pregnant employees and to increase the penalties for rape. what he saw as their stubbornness and their refusal to admit that he was "as committed as [they were] to passing any legislation needed to guarantee equal rights." ${ }^{11}$ Unfortunately for Reagan, his positions on abortion and on the ERA overshadowed his moderate Californian record and his promises to fight for equality. His election in November 1980 marked the political history of the United States by giving birth to a new phenomenon, the gender gap. For the first time, the voting pattern of women proved quite distinct from that of men, with a majority of female voters choosing the pro-women's rights candidate (Jimmy Carter) over the conservative one. In other words, the Reagan coalition of 1980 was large but it markedly did not include American women: when $56 \%$ of men voted for Reagan, only $47 \%$ of women did (Abramson, Aldrich and Rohde 96; Courtwright 165).

\section{An Anti-feminist President}

Since Reagan did not owe his election to women, they could not expect much from him when he entered the White House. And indeed they proved to be one of the social groups who suffered the most from the dramatic economic reforms he launched in 1981. These reforms were theoretically gender-neutral. But the conservative budget voted in June 1981 primarily targeted social programs which happened to mostly help women, in particular single mothers and poor minority women, such as: food stamps, Medicaid, AFDC (Aid to Families with Dependent Children), energy-assistance payments in the winter, milk programs and summer food programs in poor neighborhoods, federal subsidies to school lunches, or training programs for the unemployed. ${ }^{12}$ By the end of Reagan's first term, in 1984, social programs had seen their budget cut on average by $25 \%$, almost a million people who had been previously helped by the federal government had lost their benefits, and the number of children living in poverty had started going up again for the first time since the 1960s (Cannon 1991, 516; Barrett 405; Weatherford and McDonnell 131-132; Niskanen 267; Troy 123, 134). ${ }^{13}$

Such statistics did not really trouble President Reagan for two main reasons. First, as during the past, he considered himself a friend of women and he still could not bring himself to try to understand the animosity of women's groups towards the White House. As he confided in his diary one night:

Watched some TV in bed and saw Gloria Steinem take me over the coals for being a bigot and against women. Either she is totally ignorant of my positions which I doubt or she is a deliberate liar (Reagan 2007, 13).

Second, Reagan was in fact unable to view women as a distinct group, with distinct interests, within the body politic. His perceptions were, to use the phrase of a worried Republican Congresswoman who wrote to the President with concern, "frozen in time." ${ }^{14}$ The insight was clearly relevant as Ronald Reagan himself admitted one day in private to his friend William Buckley:

when I think or I hear the word 'woman'-true, I don't think of Lady Macbeth but then I don't think of Florence Nightingale either. I think of Nancy Reagan and Pat Buckley. Do you mind? ${ }^{15}$ 

their professional capacity. In the 1980s, two thirds of American women worked and yet, they represented only $8 \%$ of Reagan's nominees to federal positions-and these female nominees were most of the time relegated to children and family-related fields (Dallek 82). ${ }^{16}$ This troubled some of his aides, like his media guru Mike Deaver who was obsessed with the idea of taking pictures of the President being briefed by women. ${ }^{17} \mathrm{But}$ the President did not deem this necessary. For him, women in politics formed a complicated species which he found hard to comprehend and which he had divided in two categories. When they disagreed with him, he called them in private "pretty aggressive gals;" but when they supported his policies, then they became "good little girls" (Reagan 2007, 13; Barrett, 4).

17 As for the issues women's groups were fighting for, they were "unacceptable" for the White House. In the 1980s, American women's groups focused their legislative agenda on the Women's Economic Equity Act, a bill targeting the main obstacles encountered by working women (like pay discrimination or the shortage of day care centers in the US). Most Republican women in Congress supported the EEA, yet Reagan and his staff did not. They were convinced it was a bad law and it would therefore be folly to support it just "for the sake of doing something for women," as they put it. The arguments against the EEA they used among themselves are helpful to understand the substance of conservative anti-feminism. First, the law went "against the basic thrust" of Reagan's philosophy, both politically and morally. Politically, it would have given the federal government new anti-discrimination powers which went beyond what they, as smallgovernment conservatives who had promised in 1980 to reduce Washington's interventionist apparatus, called "its appropriate role." As for financially helping divorced women, this was morally inadmissible in the eyes of the Reaganites. It was "unfair" to married women and it would end up "undermin[ing] families"-one of the deepest laments of social conservatives who, since the cultural upheavals of the Sixties and the rise in the number of divorces, working women, female-headed households, and same-sex families, had grown extremely worried about the redefinition of the concept of 'family' apart from their own religious and gender-based vision (Christensen 288-291):

The more the government goes about eliminating all the economic advantages of remaining married, creating positive incentives to 'going it alone', and setting itself as a substitute spouse, the more it will contribute to the breakup of the American family.

The administration was also reluctant to use the very concept of "wage disparity." For Reagan and his advisors, it was "an idea we know to be false." Admittedly, they were ready to recognize a "pay gap" existed between men and women, but they disagreed with feminists who blamed it on gender discrimination. For the Reaganites, this situation was explained by "different experience levels:" men made more than women because they had more seniority and because they worked "for longer periods of time" throughout their lives (37 years against 26 on average). They also stressed other "nondiscriminatory factors" like "lower mobility of married women, refusal to accept as much overtime, refusal to accept supplementary training etc."-as if these were not related to the specific difficulties met by working mothers in the United States. But the most fundamental problem of the EEA, for the administration, was what it symbolized about the evolution of gender roles in contemporary America. Its bottom line was to help women work and this was not a good idea. The debate over the EEA took place 
mostly in 1982-1983, at the end of the terrible economic recession which affected the United States after Reagan's election. The coming economic recovery was in the eyes of the administration a great opportunity which should not be missed. First, because the unemployment rate would go down; and secondly, and maybe more importantly, because it would finally allow women to go back to their traditional domestic responsibilities. As one White House memo put it:

as real wages once again begin to rise, women who have been forced into the labor market to help buttress eroding family incomes will once again be freer to stay at home and care for their children..$^{18}$

Without the support of the White House, the Women's Economic Equity Act failed to pass Congress. ${ }^{19}$ Reagan's popularity with women, which was already low to start with, plummeted (he was on average between 15 to $23 \%$ less popular among women than among men). This disaffection was interestingly due less to Reagan's old opposition to the ERA than to his stances on concrete everyday life issues. White House opinion studies showed that the main problem in the eyes of his female critics was what they perceived as the lack of compassion in his social policies. Thus the demographic groups where Reagan's unpopularity was the highest were young women (under 45), women with no degrees, and single women-i.e. the part of the American population which had suffered the most from the weakening of social programs since $1981 .{ }^{20}$

Some in the administration wondered if this meant Reagan should become more open to the "feminist agenda." But his closest advisors concluded it was pointless. During a 1983 White House meeting devoted to this question, Reagan's staff concluded that no concrete gestures had to be made towards women as, according to them, "the women's issue is rhetorical." In this regard, "perceptions are more important than substance." In other words, all Reagan needed to reassure women was a "successful communication strategy." ${ }^{21}$ This may sound highly cynical. However, looking at the position of the Reagan administration on women's issues solely through the prism of conservatism and political cynicism would not provide a complete picture of what happened in the United States during those eight years. There is of course no denying that Ronald Reagan was completely at odds with the evolution of gender roles in the late $20^{\text {th }}$ century - he did not understand it, he did not approve of it. But this is not the same thing as saying that he managed to use the extensive presidential powers at his disposal to successfully stop, or even just slow down, these changes. Far from it actually: rather paradoxically, the Reagan years were, to some extent, years of progress for American women, sometimes despite Reagan, but also sometimes thanks to him.

\section{Pragmatism, Political Acumen, and Women's Issues}

21 The most striking thing when comparing the conservative promises of candidate Reagan in 1980 and the record of President Reagan in 1988 is that, as far as women's issues are concerned, Reagan was an utter failure-except regarding the ERA, although the fact that it was not ratified by enough states in the end was arguably due more to conservative activists at the grassroots level than to his own actions.

In the White House, Reagan remained very close to the Christian Right, whose leaders he regularly met. ${ }^{22}$ From a rhetorical point of view, his conservative views remained as strong as ever. For the tenth anniversary of Roe $v$. Wade for example, he published a short book to condemn abortion, Abortion and the Conscience of the Nation (1983), the first 
book ever written by a sitting President. In it, he faithfully reiterated the familiar arguments used by the Christian Right: the killing of "more than 15 million unborn children" since 1973, the unconstitutionality of Roe ("Make no mistake, abortion-ondemand is not a right granted by the Constitution."), the comparison between abortion and slavery, or the link between abortion (also called "infanticide" in the book) and eugenics (a pro-choice scientist was thus accused of suggesting that "if a handicapped child 'were not declared fully human until three days after birth, then all parents could be allowed the choice'.") (Reagan 1984, 15, 16, 19, 24-25, 32). What is more, as promised during the campaign, Reagan became the first president to support the vote of a constitutional amendment banning what he called "this abortion monster" (Reagan 2007, 126). To those who saw ideological inconsistency in a conservative president opposed to Big Government calling for such an intrusion of said government in the intimate life of American women, Reagan replied that the interests of the fetus had to prime over anything else:

I know many well-intentioned, sincerely motivated people believe that government intervention violates a womans [sic] right of choice. And they would be right if there were any proof that the unborn are not living human beings. Medical evidence indicates to the contrary. [...]

Doesn't the Constitutional protection of life, liberty, and the pursuit of happiness extend to the unborn unless it can be proven beyond a shadow of a doubt that life doesn't exist? ${ }^{23}$

Concretely however, despite such passionate claims, his anti-abortion victories were few and far between: he nominated a famous pro-life doctor, C. Everett Koop, as Surgeon General; he limited access to abortion on Indian reservations; and he ordered doctors performing abortions on underage girls to inform their parents: for Reagan, these girls were "sexually active-that has replaced the word "promiscuous"" ${ }^{24}$-a decision later struck down by a federal court. As for the most symbolic issue of all, Roe, it remained untouched during the Reagan years.

This reprieve for American women came from the fact that despite Reagan's heated rhetoric, abortion never became a priority for him. As he once admitted to one of his biographers, "social issues" like abortion were "very important" of course, yet they remained "a periphery to a philosophy," especially compared to the economy or foreign policy (Barrett 62). This hierarchy of priorities delighted Reagan's advisors. Although they shared their boss's deeply traditional and conservative view of women, they refused to push the issue as well. In private, they actually strongly disliked Christian leaders: they found them "very naive," annoying, extremist, proud, and stubborn. ${ }^{25}$ They also feared that kowtowing to them, in a country where a clear majority of people remained favorable to abortion rights, could alienate the President from millions of Americans. As a consequence, their unofficial strategy in this matter became to "provide supportive Presidential rhetoric" to pro-life groups while "leav[ing] the lead" to Congressional Republicans. ${ }^{26}$ This middle-ground made all the more sense as, even if they never admitted so publicly, the Reaganites knew perfectly well that Christian conservatives had nowhere else to go since they would never endorse a pro-choice Democrat. So even if Reagan failed to satisfy their anti-abortion demands, the risk of losing their vote was consequently non-existent (Strober and Strober 104-105)-a line of reasoning which would, years later, become the core of Thomas Frank's famous demonstration in What's the Matter with Kansas. ${ }^{27}$ 
The clearest evidence of Reagan's relative independence from the Christian Right is to be found in the nomination of Sandra Day O'Connor to the Supreme Court in the summer of 1981-one of the most significant events in the history of American women. The background to this nomination is rather revealing. At first sight, this decision can be analyzed as crassly political. After all, it had been the constant pounding on the part of women's groups during the 1980 campaign that had pushed Reagan to promise, if elected, to nominate the first woman to the Supreme Court. When he kept his word and chose Sandra Day O'Connor, a Republican judge from Arizona, his advisors were extremely pleased. They saluted the President's announcement as "a very good political move" which would "go a long way towards solving the problem we have with the lack of women in this Administration in high places" and would "take off of your back the impression, however unjustified, that you and your senior staff are antiwomen." 28

However, O'Connor's nomination was more than a smart public-relations move. It was also the result of a more complex political episode. She admittedly did not pave the way to a massive increase in the number of women among American elites. At the same time, it would be a mistake to underestimate her symbolical value. For her nomination proved a real political gamble on the part of President Reagan. As it happened, her profile proved unacceptable to religious conservatives. In the 1970s, as a state senator in Arizona, she had supported the ratification of the Equal Rights Amendment and she had voted twice to strike down anti-abortion laws in the state. Reagan knew this, and he asked her about it when he first met her. She explained that such votes did not reflect her personal views. That was enough for the President, who concluded: "She declares abortion is personally repugnant to her. I think she'll make a good Justice." (Reagan 2007, 28). ${ }^{29}$ Reagan chose to believe what O'Connor had promised to him, and from then on, he never gave another thought to her objectively pro-women's rights record and his loyalty to her proved unwavering. This was a crucial moment because it led, in many respects, to one of the worst political and ideological crises of his presidency.

Women's groups were delighted by the nomination, whereas the Christian Right was incensed. Its leaders started lobbying the White House, threatening to launch "a nasty political protest against the President." ${ }^{30}$ The staff was horrified by this reaction, and they begged Reagan to withdraw O'Connor's name. For them:

there [was] a real likelihood that this [was] going to grow into a major issue, whereby the President [would] lose the support of those people [the evangelical community] who ha[d] backed him for years. ${ }^{31}$

But Reagan would not budge. He-who could be so passive and detached from the dayto-day workings of his administration-decided to get personally involved in the fight to save Sandra Day O'Connor, whose nomination had to be confirmed by the Senate. And so he set upon calling every hesitating Republican Senator, patiently explaining to them why he was "comfortable with Judge O'Connor's position on abortion." ${ }^{32}$ This lobbying worked and despite the fury of religious conservatives, Sandra Day O'Connor was unanimously confirmed by the Senate. Clearly, American society was ready for a female Supreme Court Justice, and Ronald Reagan had felt this and had been ready to take a real risk to make it happen. The person who understood this the best was evidently Sandra Day O'Connor herself who, in a very moving letter she sent Reagan a few months later, wrote: 
I ... want to thank you on behalf of all women for making the historic decision to name a woman to the Supreme Court. My appointment has probably done more to give women confidence in true equal opportunity than a thousand speeches. ${ }^{33}$

Reagan is one of the great transformational presidents in the history of the United States. Yet, one has to admit that he did not transform all walks of life equally. The economy and the international position of the country were deeply changed by his presidency. And in many ways, so were the lives of American women. But this change went in an unexpected direction. By 1980, given the obvious hostility of Ronald Reagan to women's issues, fearing the worst after his election was a natural reaction. But in reality, in most respects, the lives of American women improved during the Reagan years and most of the progress of the 1970s was consolidated, despite the death of the ERA. Women kept their reproductive rights, they entered universities and the professions in record numbers, one of them was sitting on the Supreme Court, and millions of them benefited from the strong prosperity that returned after 1982. In other words, even though Reagan was almost ontologically unable to understand their lives, their struggles, and their demands, he and his advisors were also smart enough to realize that, in contemporary America, it would probably be political suicide to make oneself an obstacle on the path of women. This calculation worked. In the presidential election of 1984, even though the Democratic Party made history by nominating Geraldine Ferraro for the vice-presidency - the first time ever a woman appeared on a presidential ticket - the gender gap was actually reversed compared to 1980 and Ronald Reagan won a large majority of the women's vote (58\%) (Brookhiser 279; Cannon 1991, 493-494; Abramson, Aldrich and Rohde, 136-137; Ehrman, 217). In the end, his pragmatism and political acumen had served him well, a lesson lost on future generations of Republican leaders.

\section{BIBLIOGRAPHY}

\section{Archival documents}

Appointment of Marilyn Thayer and News Release, September 11, 22, 1980, folder "Meese, Ed Subject File - Women's Issues (1)", Box 136, Series III, Ed Meese Files, Ronald Reagan 1980 Presidential Campaign Papers, 1965-1980, Ronald Reagan Library.

Bill Casey Memo, September 17, 1980, folder “Meese, Ed - Subject File - Women's Issues (1)”, Box 136, Series III, Ed Meese Files, Ronald Reagan 1980 Presidential Campaign Papers, 1965-1980, Ronald Reagan Library.

Bobbi Fiedler letter, August 27, 1983, folder "White House Staff Memoranda - Cabinet Affairs (2 of 3)”, Box 3, Baker, James A. III - Files 1981-1985, Series I, Ronald Reagan Library.

Camp David Follow-Up, February 8, 1982, folder “Camp David Briefing 02/05/1982 (1)”, Box 2, Darman, Richard, Series I - Subject File, Ronald Reagan Library. 
Candidacy of Judge O'Connor for the Supreme Court Memorandum, July 6, 1981, folder "OA 2408, Appointments - Supreme Court - O'Connor (1)”, Box 7, Meese, Edwin - Files OA 2408, 2409, Ronald Reagan Library.

Dear Christian Leader Letter, folder “Campaign Operations - Voter Groups Update (2)”, Box 248, Series VII, Campaign Operations (Deaver), Ronald Reagan 1980 Presidential Campaign Papers, 1965-1980, Ronald Reagan Library.

Dodie Memo, April 29, 1980, folder "Meese, Ed - Campaign Planning - Political Memos, April 1980", Box 103, Series III, Ed Meese Files, Ronald Reagan 1980 Presidential Campaign Papers, 1965-1980, Ronald Reagan Library.

Ed Thomas Memorandum, July 27, 1981, folder “OA 2408, Appointments - Supreme Court O'Connor (1)”, Box 7, Meese, Edwin - Files OA 2408, 2409, Ronald Reagan Library.

Entitlements Memoranda, October 1981, folder “OA 5102 Entitlement 10/25/1981 (binder)", Box 19, Meese, Edwin - Files OA 5102-5103, 6191-6193, Ronald Reagan Library.

ERA Talking Points, folder “Meese, Ed - Background Material - Issues, 1979 (1)”, Box 159, Series III, Ed Meese Files, Ronald Reagan 1980 Presidential Campaign Papers, 1965-1980, Ronald Reagan Library.

Final Control Numbers for Economic Program, February 17, 1981, folder “OA 11834, OMB Budget Reform Plan (1)", Box 43, Meese, Edwin - Files OA 11833-11834, Ronald Reagan Library.

Information for Meeting with Republican Congresswomen Memorandum, March 4, 1983, folder “OA 11841, Women's Issues (11)", Box 52, Meese, Edwin - Files OA 11841, 11842, 11843, Ronald Reagan Library.

Kenneth W. Starr Memorandum for the Attorney General, July 7, 1981, folder "OA 2408, Appointments - Supreme Court - O'Connor (1)”, Box 7, Meese, Edwin - Files OA 2408, 2409, Ronald Reagan Library.

Legislative/Administrative Proposals on Women's Initiatives, June 23, 1983, folder “OA 10871 Women's Issues, (2)", Box 23, Deaver, Michael K. - Files OA 10869, 10870, 10781, Ronald Reagan Library.

Letter to William F. Buckley, September 6, 1983, folder "Folder 95 (8/20/83-9/6/83)", Box 7, Presidential Handwriting File - Series II - Presidential Records, Ronald Reagan Library.

Lyn Nofziger Memorandum, January 21, 1981, folder “OA 9448, Conservative Groups - The Conservative Caucus”, Box 26, Meese, Edwin - Files OA 9448, 9449, Ronald Reagan Library.

Lyn Nofziger Memorandum for the President, June 22, 1981, folder "Folder 6 (7/16/81-8/17/81)", Box 1, Presidential Handwriting File - Series II - Presidential Records, Ronald Reagan Library.

Lynne Arena Memorandum, October 13, 1980, folder “Meese, Ed - Subject File - Women's Issues (3)”, Box 136, Series III, Ed Meese Files, Ronald Reagan 1980 Presidential Campaign Papers, 1965-1980, Ronald Reagan Library.

Meeting with Republican Congresswomen Memorandum, folder “OA 11841, Women's Issues (10)", Box 52, Meese, Edwin - Files OA 11841, 11842, 11843, Ronald Reagan Library.

Memorandum for Dick Wirthlin, September 10, 1980, folder "Political Operations - Voter Groups - Christians, Evangelicals (1)", Box 255, Series VIII, William Timmons General, Ronald Reagan 1980 Presidential Campaign Papers, 1965-1980, Ronald Reagan Library. 
Memorandum for the Budget Review Board and Participants at Monday's Meeting, October 30, 1981, folder “OA 5102 Entitlement 10/31/1981 (binder)", Box 19, Meese, Edwin - Files OA 5102-5103, 6191-6193, Ronald Reagan Library.

News Release, October 21, 1980, folder “Meese, Ed - Subject File - Women's Issues (3)", Box 136, Series III, Ed Meese Files, Ronald Reagan 1980 Presidential Campaign Papers, 1965-1980, Ronald Reagan Library.

Presidential Remarks: Annual Convention of National Religious Broadcasters, January 31, 1983, folder "Folder 140 (1/31/83 cont.)", Box 8, Presidential Handwriting File - Series III - Presidential Speeches, Ronald Reagan Library.

Presidential Remarks: Dropby Briefing for Women Leaders of Christian Religious Organizations, October 12, 1983, folder "Folder 220 (10/8/83-10/12/83)", Box 12, Presidential Handwriting File Series III - Presidential Speeches, Ronald Reagan Library.

Reagan's Shift to the Center Raises Clamor On the Right, New York Times article, July 12, 1981, folder "OA 2408, Appointments - Supreme Court - O'Connor (1)", Box 7, Meese, Edwin - Files OA 2408, 2409, Ronald Reagan Library.

Requests Made by Congresswomen Memorandum, March 29, 1983, folder “OA 11841, Women's Issues (10)", Box 52, Meese, Edwin - Files OA 11841, 11842, 11843, Ronald Reagan Library.

Ronald Reagan's Religion, folder “Hannaford - California Headquarters - Ronald Reagan Religious Belief”, Box 45, Series I, Hannaford - California Headquarters, Ronald Reagan 1980 Presidential Campaign Papers, 1965-1980, Ronald Reagan Library.

Sandra Say O'Connor letter, October 13, 1981, folder “Folder 11 (10/11/81-10/16/81)", Box 1, Presidential Handwriting File - Series II - Presidential Records, Ronald Reagan Library.

Senior Staff Meeting Action Items, December 20, 1982, folder “OA 8546 Senior Staff Meeting 1982 (December 1982)", Box 14, Deaver, Michael K. - Files OA 8546, Ronald Reagan Library.

Senior Staff Meeting Action Items, January 22, 1982, folder “OA 8546 Senior Staff Meeting 1982 (January 1982)”, Box 14, Deaver, Michael K. - Files OA 8546, Ronald Reagan Library; Presidential Address: National Association of Evangelicals, March 8, 1983.

Senior Staff Meeting Action Items, July 13, 1981, folder “OA 8546 Senior Staff Meeting 1981 (3)”, Box 14, Deaver, Michael K. - Files OA 8546, Ronald Reagan Library.

Stiff Tax Hikes Will Be Key to Future Efforts to Close the Budget Deficit, National Journal article, April 21, 1984, folder “Tax Simplification [1982-1984] (1)”, Box 6, Darman, Richard, Series I-Series II, Ronald Reagan Library.

Strom Thurmond letter, July 7, 1981, folder “OA 2408, Appointments - Supreme Court - O'Connor (2)", Box 7, Meese, Edwin - Files OA 2408, 2409, Ronald Reagan Library.

Update on Women's Issues, June 30, 1983, folder “OA 11841, Women's Issues (8)”, Box 52, Meese, Edwin - Files OA 11841, 11842, 11843, Ronald Reagan Library.

Voter Group Survey Research Memorandum, September 2, 1980, folder “Media Campaign - Voter Block (1)", Box 228, Series V, Media, Promotion, Advertising (Daley) - Media Campaign, Ronald Reagan 1980 Presidential Campaign Papers, 1965-1980, Ronald Reagan Library.

Women Constituency Support Memorandum, May 6, 1982, folder “OA 9461, Women's Issues (5)", Box 33, Meese, Edwin - Files OA 9461-9462, Ronald Reagan Library. 
Women \& ERA Memorandum, June 25, 1980, folder “Meese, Ed - Campaign Planning - Political Memos, June 1980", Box 103, Series III, Ed Meese Files, Ronald Reagan 1980 Presidential Campaign Papers, 1965-1980, Ronald Reagan Library.

Women's Groups Fault Reagan on Jobs and Issues, New York Times article, May 21, 1982, folder "OA 9461, Women's Issues (4)”, Box 33, Meese, Edwin - Files OA 9461-9462, Ronald Reagan Library.

\section{Books}

Abramson, Paul R., John H. Aldrich and David W. Rohde. Change and Continuity in the 1980 Elections. Washington, D.C.: CQ Press, 1983.

Balmer, Randall. Thy Kingdom Come: How the Religious Right Distorts the Faith and Threatens America, an Evangelical's Lament. New York: Basic Books, 2006.

Barrett, Laurence I. Gambling with History: Ronald Reagan in the White House. New York: Doubleday \& Company, Inc., 1983.

Brookhiser, Richard. The Outside Story: How Democrats and Republicans Re-Elected Reagan. Garden City, New York: Doubleday \& Company, 1986.

Cannon, Lou. Governor Reagan: His Rise to Power. New York: Public Affairs, 2003.

---. President Reagan: The Role of a Lifetime. New York: Simon \& Schuster, 1991.

Christensen, Bryce J. “Family." In American Conservatism, An Encyclopedia. Eds. Bruce Frohnen, Jeremy Beer, and Jeffrey O. Nelson. Wilmington: ISI Books, 2006. 288-291.

Colacello, Bob. Ronnie \& Nancy: Their Path to the White House, 1911 to 1980. New York: Warner Books, 2004.

Courtwright, David T. No Right Turn: Conservative Politics in a Liberal America. Cambridge, Massachusetts: Harvard University Press, 2010.

Dallek, Robert. Ronald Reagan: The Politics of Symbolism. Cambridge: Harvard University Press, 1999. Diamond, Sara. Roads to Dominion: Right-Wing Movements and Political Power in the United States. New York: The Guilford Press, 1995.

Dicker, Rory. A History of U.S. Feminisms. Berkeley: Seal Press, 2008.

Ehrman, John. The Eighties: America in the Age of Reagan. New Haven: Yale University Press, 2005.

Faludi, Susan. Backlash, The Undeclared War Against American Women. New York: Three Rivers Press, 1991.

Martin, William. With God on Our Side: The Rise of the Religious Right in America. New York: Broadway Books, 1996.

Morris, Edmund. Dutch: A Memoir of Ronald Reagan. London: HarperCollinsPublisher, 1999.

Niskanen, William A. Reaganomics: An Insider's Account of the Policies and the People. New York: Oxford University Press, 1988.

Reagan, Ronald. Abortion and the Conscience of the Nation. New York: Thomas Nelson Publishers, 1984.

---. An American Life. New York: Simon \& Schuster, 1990.

---. A Life in Letters, Edited by Kiron K. Skinner, Annelise Anderson and Martin Anderson. New York: Free Press, 2004.

---. The Reagan Diaries. New York: Harper Perennial, 2007. 
Reagan, Ronald and Richard G. Hubler. Where's the Rest of Me? New York: A Dell Book, 1965.

Strober, Deborah Hart and Gerald S. Strober. The Reagan Presidency: An Oral History of the Era. Washington D.C.: Brassey's Inc, 2003.

Troy, Gil. Morning in America: How Ronald Reagan Invented the 1980s. Princeton: Princeton University Press, 2005.

Vaughn, Stephen. Ronald Reagan in Hollywood: Movies and Politics. Cambridge: Cambridge University Press, 1994.

Weatherford, Stephen M. and Lorraine M. McDonnell. "Ideology and Economic Policy." In Looking Back on the Reagan Presidency. Ed. Larry Berman. Baltimore: The Johns Hopkins University Press, 1990. 122-155.

\section{Internet Sources}

Reagan, Ronald. "Republican National Convention Acceptance Speech.” The Ronald Reagan Presidential Library (July 17, 1980) 10 Sept 2014 <http://www.reagan.utexas.edu/archives/ reference/7.17.80.html>.

\section{NOTES}

1. See Faludi, Susan, Backlash. The Undeclared War Against American Women. New York: Three Rivers Press, 1991.

2. The Evangelical movement is defined by three main elements: a literal interpretation of the Bible; the belief that religious conversion (through a 'born-again' experience) is necessary to be saved; and a prosyletic attitude towards non-Evangelical people (see Randall Balmer, Thy Kingdom Come: How the Religious Right Distorts the Faith and Threatens America, an Evangelical's Lament, Basic Books, New York, 2006).

3. Ronald Reagan's Religion, International Christian Ministries article, folder "Hannaford California Headquarters - Ronald Reagan Religious Belief”, Box 45, Series I, Hannaford California Headquarters, Ronald Reagan 1980 Presidential Campaign Papers, 1965-1980, Ronald Reagan Library; Dear Christian Leader Letter, folder "Campaign Operations - Voter Groups Update (2)", Box 248, Series VII, Campaign Operations (Deaver), Ronald Reagan 1980 Presidential Campaign Papers, 1965-1980, Ronald Reagan Library.

4. ERA Talking Points, folder "Meese, Ed - Background Material - Issues, 1979 (1)", Box 159, Series III, Ed Meese Files, Ronald Reagan 1980 Presidential Campaign Papers, 1965-1980, Ronald Reagan Library.

5. Women \& ERA Memorandum, June 25, 1980, folder "Meese, Ed - Campaign Planning - Political Memos, June 1980", Box 103, Series III, Ed Meese Files, Ronald Reagan 1980 Presidential Campaign Papers, 1965-1980, Ronald Reagan Library; Voter Group Survey Research Memorandum, September 2, 1980, folder "Media Campaign - Voter Block (1)", Box 228, Series V, Media, Promotion, Advertising (Daley) - Media Campaign, Ronald Reagan 1980 Presidential Campaign Papers, 1965-1980, Ronald Reagan Library.

6. Dodie Memo, April 29, 1980, folder "Meese, Ed - Campaign Planning - Political Memos, April 1980", Box 103, Series III, Ed Meese Files, Ronald Reagan 1980 Presidential Campaign Papers, 1965-1980, Ronald Reagan Library.

7. Voter Group Survey Research Memorandum, September 2, 1980.

8. Lynne Arena Memorandum, October 13, 1980, folder "Meese, Ed - Subject File - Women's Issues (3)", Box 136, Series III, Ed Meese Files, Ronald Reagan 1980 Presidential Campaign Papers, 1965-1980, Ronald Reagan Library. 
9. Appointment of Marilyn Thayer and News Release, September 11, 22, 1980, folder "Meese, Ed Subject File - Women's Issues (1)", Box 136, Series III, Ed Meese Files, Ronald Reagan 1980 Presidential Campaign Papers, 1965-1980, Ronald Reagan Library.

10. Bill Casey Memo, September 17, 1980, folder "Meese, Ed - Subject File - Women's Issues (1)", Box 136, Series III, Ed Meese Files, Ronald Reagan 1980 Presidential Campaign Papers, 1965-1980, Ronald Reagan Library.

11. News Release, October 21, 1980, folder "Meese, Ed - Subject File - Women's Issues (3)", Box 136, Series III, Ed Meese Files, Ronald Reagan 1980 Presidential Campaign Papers, 1965-1980, Ronald Reagan Library.

12. Final Control Numbers for Economic Program, February 17, 1981, folder "OA 11834, OMB Budget Reform Plan (1)", Box 43, Meese, Edwin - Files OA 11833-11834, Ronald Reagan Library; Entitlements Memoranda, October 1981, folder "OA 5102 Entitlement 10/25/1981 (binder)", Box 19, Meese, Edwin - Files OA 5102-5103, 6191-6193, Ronald Reagan Library; Memorandum for the Budget Review Board and Participants at Monday's Meeting, October 30, 1981, folder "OA 5102 Entitlement 10/31/1981 (binder)”, Box 19, Meese, Edwin - Files OA 5102-5103, 6191-6193, Ronald Reagan Library.

13. See also: Stiff Tax Hikes Will Be Key to Future Efforts to Close the Budget Deficit, National Journal article, April 21, 1984, folder “Tax Simplification [1982-1984] (1)", Box 6, Darman, Richard, Series I-Series II, Ronald Reagan Library.

14. Bobbi Fiedler letter, August 27, 1983, folder "White House Staff Memoranda - Cabinet Affairs (2 of 3)", Box 3, Baker, James A. III - Files 1981-1985, Series I, Ronald Reagan Library.

15. Letter to William F. Buckley, September 6, 1983, folder "Folder 95 (8/20/83-9/6/83)", Box 7 , Presidential Handwriting File - Series II - Presidential Records, Ronald Reagan Library.

16. See also: Women's Groups Fault Reagan on Jobs and Issues, New York Times article, May 21, 1982, folder “OA 9461, Women's Issues (4)”, Box 33, Meese, Edwin - Files OA 9461-9462, Ronald Reagan Library.

17. Senior Staff Meeting Action Items, July 13, 1981, folder “OA 8546 Senior Staff Meeting 1981 (3)”, Box 14, Deaver, Michael K. - Files OA 8546, Ronald Reagan Library; Senior Staff Meeting Action Items, December 20, 1982, folder "OA 8546 Senior Staff Meeting 1982 (December 1982)", Box 14, Deaver, Michael K. - Files OA 8546, Ronald Reagan Library.

18. Update on Women's Issues, June 30, 1983, folder “OA 11841, Women's Issues (8)", Box 52, Meese, Edwin - Files OA 11841, 11842, 11843, Ronald Reagan Library; Meeting with Republican Congresswomen Memorandum, folder “OA 11841, Women's Issues (10)”, Box 52, Meese, Edwin Files OA 11841, 11842, 11843, Ronald Reagan Library; Information for Meeting with Republican Congresswomen Memorandum, March 4, 1983, folder “OA 11841, Women's Issues (11)”, Box 52, Meese, Edwin - Files OA 11841, 11842, 11843, Ronald Reagan Library; Requests Made by Congresswomen Memorandum, March 29, 1983, folder “OA 11841, Women's Issues (10)”, Box 52, Meese, Edwin - Files OA 11841, 11842, 11843, Ronald Reagan Library. The EEA was only adopted under Bill Clinton's presidency, in 1994.

19. The EEA was only adopted under Bill Clinton's presidency, in 1994.

20. Legislative/Administrative Proposals on Women's Initiatives, June 23, 1983, folder “OA 10871 Women's Issues, (2)", Box 23, Deaver, Michael K. - Files OA 10869, 10870, 10781, Ronald Reagan Library; Women Constituency Support Memorandum, May 6, 1982, folder "OA 9461, Women's Issues (5)", Box 33, Meese, Edwin - Files OA 9461-9462, Ronald Reagan Library.

21. The meeting had been called by Reagan's closest political advisor, Ed Meese, and its official topic was: "Given that much of the feminist agenda is unacceptable, what proposals which are considered favorable to women can the Administration support?". Women's Issue Meeting Conference Report, April 6, 1983, folder “OA 11841, Women's Issues (11)”, Box 52, Meese, Edwin Files OA 11841, 11842, 11843, Ronald Reagan Library. 
22. See for example: Presidential Remarks: Dropby Briefing for Women Leaders of Christian Religious Organizations, October 12, 1983, folder "Folder 220 (10/8/83-10/12/83)", Box 12, Presidential Handwriting File - Series III - Presidential Speeches, Ronald Reagan Library.

23. One can note that this passage was not drafted by Reagan's team of speechwriters but was added by Reagan himself in the text of the speech he was to give to the National Religious Broadcasters. See: Presidential Remarks: Annual Convention of National Religious Broadcasters, January 31, 1983, folder “Folder 140 (1/31/83 cont.)", Box 8, Presidential Handwriting File - Series III - Presidential Speeches, Ronald Reagan Library.

24. Senior Staff Meeting Action Items, January 22, 1982, folder "OA 8546 Senior Staff Meeting 1982 (January 1982)”, Box 14, Deaver, Michael K. - Files OA 8546, Ronald Reagan Library; Presidential Address: National Association of Evangelicals, March 8, 1983.

25. Eddie Mahe, Jr. Memorandum for Dick Wirthlin, September 10, 1980, folder "Political Operations - Voter Groups - Christians, Evangelicals (1)”, Box 255, Series VIII, William Timmons General, Ronald Reagan 1980 Presidential Campaign Papers, 1965-1980, Ronald Reagan Library; Reagan's Shift to the Center Raises Clamor On the Right, New York Times article, July 12, 1981, folder “OA 2408, Appointments - Supreme Court - O'Connor (1)", Box 7, Meese, Edwin - Files OA 2408, 2409, Ronald Reagan Library.

26. Camp David Follow-Up, February 8, 1982, folder “Camp David Briefing 02/05/1982 (1)", Box 2, Darman, Richard, Series I - Subject File, Ronald Reagan Library.

27. Lyn Nofziger Memorandum, January 21, 1981, folder "OA 9448, Conservative Groups - The Conservative Caucus", Box 26, Meese, Edwin - Files OA 9448, 9449, Ronald Reagan Library.

28. Lyn Nofziger Memorandum for the President, June 22, 1981, folder "Folder 6 (7/16/81-8/17/81)", Box 1, Presidential Handwriting File - Series II - Presidential Records, Ronald Reagan Library.

29. Strom Thurmond letter, July 7, 1981, folder "OA 2408, Appointments - Supreme Court O'Connor (2)”, Box 7, Meese, Edwin - Files OA 2408, 2409, Ronald Reagan Library; Kenneth W. Starr Memorandum for the Attorney General, July 7, 1981, folder "OA 2408, Appointments Supreme Court - O'Connor (1)", Box 7, Meese, Edwin - Files OA 2408, 2409, Ronald Reagan Library. 30. Candidacy of Judge O'Connor for the Supreme Court Memorandum, July 6, 1981, folder "OA 2408, Appointments - Supreme Court - O'Connor (1)”, Box 7, Meese, Edwin - Files OA 2408, 2409, Ronald Reagan Library.

31. Ed Thomas Memorandum, July 27, 1981, folder "OA 2408, Appointments - Supreme Court O'Connor (1)", Box 7, Meese, Edwin - Files OA 2408, 2409, Ronald Reagan Library.

32. Recommended Telephone Call Memorandum, September 16, 1981, folder "OA 2408, Appointments - Supreme Court - O'Connor (2)”, Box 7, Meese, Edwin - Files OA 2408, 2409, Ronald Reagan Library.

33. Sandra Say O'Connor letter, October 13, 1981, folder "Folder 11 (10/11/81-10/16/81)", Box 1, Presidential Handwriting File - Series II - Presidential Records, Ronald Reagan Library.

\section{ABSTRACTS}

Ronald Reagan is renowned for the conservative revolution he launched in the United States. His conservative ideology had a strong economic component, but it was also moral and cultural. Reagan's political career coincided with the emergence and the first successes of the feminist movement in the US, as he was first elected in 1966. From the beginning, Reagan remained 
steeped in a traditional-even at times archaic-vision of the relationship between men and women and of the role of women in contemporary society. He consequently expressed the utmost incomprehension towards the motivations and aspirations of feminist activists and he made his opposition to their demands (like abortion rights) one of the main themes of his political message. However he failed once in the White House to advance this anti-feminist agenda as American society was much more open-minded than its president on such issues.

Ronald Reagan est connu pour la révolution conservatrice qu'il a lancée aux Etats-Unis. Son conservatisme était bien sûr économique, mais il avait également une forte dimension morale et culturelle. La carrière politique de Reagan s'est déroulée en parallèle avec l'émergence et le développement $\mathrm{du}$ mouvement féministe aux Etats-Unis, sa première élection en Californie datant de 1966. Mais dès le début, Reagan montra la plus grande incompréhension envers le combat mené par les militantes féministes. Ancré dans une vision traditionnelle, voire archaïque, des rapports hommes-femmes et du rôle des femmes dans la société contemporaine, il a fait de l'opposition aux grandes conquêtes féministes (comme le droit à l'avortement) l'un des principaux éléments de son corpus idéologique. Pourtant, arrivé au pouvoir, il a largement échoué à imposer sa vision anti-féministe, preuve que la société américaine était bien plus ouverte que son président sur ces questions-là.

\section{INDEX}

Mots-clés: Ronald Reagan, conservatisme, féminisme, avortement, Sandra Day O'Connor Keywords: Ronald Reagan, conservatism, feminism, abortion, Sandra Day O'Connor

\section{AUTHORS}

\section{FRANÇOISE COSTE}

Maître de conférences

Université Toulouse-Jean Jaurès

francoste@hotmail.com 